\title{
Renewable Energy Attitudes and Behaviour of Local Governments in Poland
}

\author{
Joanna Rakowska *(D) and Irena Ozimek
}

check for

updates

Citation: Rakowska, J.; Ozimek, I. Renewable Energy Attitudes and Behaviour of Local Governments in Poland. Energies 2021, 14, 2765. https://doi.org/10.3390/en14102765

Academic Editor: Piotr Gradziuk

Received: 30 March 2021

Accepted: 7 May 2021

Published: 12 May 2021

Publisher's Note: MDPI stays neutral with regard to jurisdictional claims in published maps and institutional affiliations.

Copyright: (c) 2021 by the authors. Licensee MDPI, Basel, Switzerland. This article is an open access article distributed under the terms and conditions of the Creative Commons Attribution (CC BY) license (https:// creativecommons.org/licenses/by/ $4.0 /)$.
Institute of Economics and Finance, Warsaw University of Life Sciences-SGGW, 02-787 Warsaw, Poland; irena_ozimek@sggw.edu.pl

* Correspondence: joanna_rakowska@sggw.edu.pl

\begin{abstract}
The deployment of renewable energy at the local level can contribute significantly to mitigating climate change, improving energy security and increasing social, economic and environmental benefits. In many countries local authorities play an important role in the local development, but renewable energy deployment is not an obligatory task for them. Hence there are two research questions: (1) Do local governments think investments in renewable energy (RE) are urgent and affordable within the local budgets? (2) How do they react to the public aid co-financing investments in renewable energy? To provide the answer we performed qualitative analysis and non-parametric tests of data from a survey of 252 local authorities, analysis of 292 strategies of local development and datasets of 1170 renewable energy projects co-financed by EU funds under operational programs 2007-2013 and 2014-2020 in Poland. Findings showed that local authorities' attitudes were rather careful, caused by financial constraints of local budgets and the scope of obligatory tasks, which made renewable energy investments not the most urgent. Public aid was a factor significantly affecting local authorities' behavior. It triggered local authorities' renewable energy initiatives, increasing the number and scope of renewable energy investments as well cooperation with other municipalities and local communities. Despite this general trend, there were also considerable regional differences in local authorities' renewable energy behavior.
\end{abstract}

Keywords: renewable energy; local authorities; European Union funds

\section{Introduction}

Do local governments think investments in renewable energy are urgent and affordable within the local budgets? How do they react to the public aid co-financing investments in renewable energy? The crucial and still growing role of renewable energy sources in meeting the urgent need of mitigating climate change, improving energy security and increasing social, economic and environmental benefits has been well recognised and acknowledged [1-6]. Despite all the drawbacks of fossil fuel energy use and benefits of renewable energy (RE), the deployment of renewable energy happens neither on its own nor fast enough [7-9]. It needs to be policy-driven [10-14], supported by adequate legal regulations, international and national strategies, and public aid and incentives [15-19] addressed to relevant beneficiaries. Local governments are considered very important entities in the process of increasing renewable energy production and use at the local level, in many economic, social and political contexts. However, the literature lacks cohesive conclusions on the renewable energy attitudes and behavior of local governments in Poland. This study aims to fill this gap.

\section{Literature Review}

The European Union began to build its policy framework for renewable energy in 1997 with the White Paper for a Community Strategy and Action Plan Energy for the future: Renewable sources of energy [20], setting basis for the policy on renewable energy. The policy has significantly evolved afterwards [21-26]. The recent legal framework for the 
promotion of renewable energy sources until 2020 was laid down in directive adopted in 2009 [27], while renewable energy production and consumption goals until 2030 are set in the Regulation on the Governance of the Energy Union and Climate Action (EU) 2018/1999 [28], for the EU as a whole and for its individual member states [29].

To promote renewable energy and thus achieve climate goals, the EU applies Cohesion policy instruments, including structural and cohesion funds. They are said to be the most important funding sources for promoting renewable energy among the EU spending programmes, of continusly increasing value-from only 600 million euro during the 2000-2006 programming period, through approximately 4.7 billion euro in the 2007-2013, up to 27 billion euro in 2014-2020 [30]. The EU policy is based on the already well verified assumption that decarbonisation requires solutions at all levels of governance and collaboration - global, regional, national and especially local [31-37].

The focus on the deployment of renewable energy at the local level results from its positive impact on local communities, economies and environment. Renewable energy production and use provide new job opportunities [38-40], cause income generation, diversification of economic activities, use of endogenous resources [41], contribute to satisfying local energy demands [42,43], are drivers of economic recovery in peripheral or remote areas [44-46] and drivers of relevant business opportunities in large metropolitan areas [47]. Renewable energy enables transfer to community-owned energy sources [48,49], decentralisation of energy production and supplies [50,51], even local and regional energy autarky [52-55]. Renewable energy can cause such externalities as positive health effects [56]. However, achieving these benefits requires social capital [57] and the involvement of local actors. Local authorities are of particular significance in this process.

Many studies, providing insight into different political, economic and administrative backgrounds argue that local authorities can play a key role in promoting renewable energy production and use [58-62]. Local authorities can initiate, invest, produce and be the end users of renewable energy [63-66]. Due to the importance of renewable energy the EU addresses its structural funds also to potential beneficiaries who can invest in renewable energy. Local authorities implement some of the state's tasks on a local scale because they have the best knowledge of local factors and development conditions as well as of the needs of local communities. This enables a more accurate adjustment of the supply of public goods and services to local demand. Such approach is in line with the principle of subsidiarity enforced in the cohesion policy of the EU [67]. It orders the decentralization of activities and the delegation of decision-making and executive powers to the lowest possible level of administration, capable of implementing them, in order to ensure the most effective use of public funds. The principle of subsidiarity is anchored in Art. 4, Section 3 of the European Charter of Local Self-Government [68]. Despite this general rule, local authorities in individual member states of the EU have different obligatory and facultative tasks to perform, as well as different measures to obtain their goals. Thus they also play different roles in supporting renewable energy deployment at the local level.

In the Polish legal system, there are currently three main statutory acts that directly regulate the production and use of renewable energy. These are: the Act of 10 April 1997 Energy Law [69], the Act of 20 February 2015 on renewable energy sources [70], and the Act of 20 May 2016 on investments in wind farms [71]. The Act of 20 February 2015 on renewable energy sources defines renewable energy sources as renewable, non-fossil energy sources, including wind energy, energy solar radiation, aerothermal energy, geothermal energy, hydrothermal energy, hydropower, wave, current and tidal energy, energy obtained from biomass, biogas, agricultural biogas and bioliquids. The Energy Law Act specifies, among other, the development of the use of renewable energy installations and provides for certain tasks and competences of administrators, also in relation to local authorities (Articles 17-19 of the EPA). According to Polish law local authorities in Poland are to create and implement the development policy and monitor its effects, using the instruments available and effective in the given conditions [72]. They can support the deployment of renewable energy within their own public tasks, in order to meet the needs of the local 
community, as pursuant to the Act of 8 March 1990 on the commune self-government [73], art. $7 \mathrm{sec}$. 1, they are responsible for 'meeting the collective needs of the community'. Electricity, heat and gas supplies are mentioned expressis verbis among the tasks of the local government.

In Poland, local authorities of municipalities (called in Polish 'gmina' and classified by the European Union as lower LAUs [74]) which are the basic local government unit, can play a special role on the energy market and in the field of renewable energy sources. On one hand, they can independently create energy through their own activities, and on the other hand, they can support the development of energy in their area, due to the applicable regulations [75]. According to some authors [76], a commune and its local authority may act as 'an energy user and a participant in the competitive energy market, as a local energy regulator, as an investor and producer of energy, and as an entity responsible for planning and financing the lighting of public places and roads within its area'. It should be stressed however, that Polish law does not give local authorities too many tools to effectively stimulate the development of renewable energy. The law does not introduce a transparent system of tasks of competences of the administrative entities, in particular in case of the local government [77]. Summing up, Polish local authorities are allowed to, but do not have to support renewable energy.

The European Union structural and cohesion funds allocated in eligible member states in consequent budget perspectives under operational programmes of regional policy were to suport member states also in deploying renewable energy and in achieving overall national targets in this field [78]. In 2007-2013 EU funds co-financing renewable energy investments were available in Poland from the Operational Program Infrastructure and Environment 2007-2013, which received the highest EU funding for any operational program in the history of the EU regional and cohesion policy and from 16 regional operational programs [79]. In financial perspective of 2014-2020 renewable energy projects were supported by EU funds under 16 regional operational programmes. In both these financial perspectives EU funds for renewable energy projects have been addressed to many groups of potential beneficiaries, including local governments.

The review of literature provides theoretical assumptions on the role of local governments in deployment of renewable energy, while the European Union and national legal frameworks together with the EU financial support give local governments opportunities to actively participate in renewable energy deployment. Despite all the above, the literature lacks a broader insight into renewable energy attitudes of local governments in Poland. It also lacks comparative analysis of local governments behavior related to the deployment of renewable energy, supported by EU funds in 2007-2013 and 2014-2020 financial perspectives. The aim of this study is to fill in this gap.

\section{Materials and Methods}

The main aim of the study was to answer the following research questions on the attitudes and behavior of local governments: (1) Do local governments think investments in renewable energy are urgent and affordable within the local budgets? (2) How do they react to the public aid co-financing investments in renewable energy? To answer these questions, the study was based on qualitative and quantitative data analyses.

The attitudes of local governments to renewable energy investments were analysed based on the answers to the first research questions, i.e., whether local governments think that investments in renewable energy are urgent and affordable within the local budgets. The data used to answer these questions came from two sources: (i) a survey of local governments of municipalities of Mazovian Voivodship and (ii) a qualitative analysis of data obtained from the strategies of development of municipalities of Mazovian Voivodship. Both analyses were carried out for the municipalities of Mazovian, which is currently NUTS 1 by Eurostat [80]. It was selected for the survey, as it is the largest voivodship in Poland, both in terms of population and the area. At the same time it is a voivodship with the biggest number of municipalities and consequently the largest number 
of local governments, which are a subject of this research. As the local governments have been functioning within the borders of the same region, they have been addressees of the same regional operational programmes for 2007-2013 and 2014-2020. On the other hand, municipalities of Mazovian Voivodship represent very different types concerning population, population density, total annual budget revenues, rural-urban categories, etc. All these give rationale for the studying the attitudes of local governments to renewable energy investments based on municipalities of Mazovian Voivodship.

The survey questionnaire was sent by mail to governments of all 314 municipalities of Mazovian Voivodship in 2017. The response rate reached $62 \%$. The questionnaire included questions that were compiled to avoid suggesting any answers. The respondents were asked: (i) what investments, that could be carried out by the self-government, were most urgent? (ii) what investments were necessary to improve the quality of natural environment in the municipality? (iii) how they assessed the quality of natural environment in the municipality? (iv) what were the biggest obstacles in supporting the development of the municipalities by local governments?

Strategies of local development of 292 municipalities of Mazovian Voivodship were another source of qualitative data used for the investigation into the attitudes of local self-governments to renewable energy investments. The strategies were retrieved from the websites of municipalities between 3 January 2021 and 20 January 2021. Based on these, we studied $93 \%$ of all 314 municipalities of this voivodship. Strategies of local development for the remaining 22 municipalities were not available. In Poland, pursuant to the Act of 8 March 1990 on the municipality government [73], the municipality may develop a development strategy. Although strategies are not obligatory, they are a great help in effective acquisition of funds from European funds and other external sources, including funds for the development of energy from renewable sources.

The retrieved strategies were analysed to find answer to the following, set a priori, research questions: (i) does the strategy include any plans for renewable energy investments? (ii) If so, is the type of renewable energy investment defined? (iii) What type is it (solar, wind, biomass etc.), if defined? (iv) Is the source of financing for renewable energy investments indicated (domestic, EU etc.)? (v) Are the conditions for renewable energy investments favorable in the municipality? (vi) If so, what kind of renewable energy investments are the conditions good for?

The behaviour of local self-governments in the field of renewable energy was analyzed based on qualitative and quantitative data on projects (investments) in renewable energy made by all municipalities in Poland under the 2007-2013 and 2014-2020 operational programs co-financed by the European Union funds (Table 1).

The TERYT codes, names and types of administrative units, as well as addresses and codes of municipality offices were used to verify, complete and merge the datasets, as well as to carry out data curation. To analyze qualitative data we used standard qualitative analysis tools [81-83].

To analyse quantitative data we first applied selected methods of descriptive statistics and tested the distribution of quantitative variables using Kolmogorov-Smirnov test. As the results showed that the distribution of the majority of variables is non-normal, the further analysis was performed using non-parametric tests, including and Kruskal-Wallis $\mathrm{H}$ test, Mann-Whitney $U$ test together with Wilcoxon rank-sum test and Wilcoxon signed-rank test (Table 2). We applied these non-parametric tests as they are appropriate to obtain answers to our research questions based on variables of non-normal distribution. 
Table 1. Data categories and sources.

\section{Data Categories}

Description and Sources

Qualitative and quantitative data on projects carried out in Poland under Operational Programmes 2007-2013, obtained from the National Information System SIMIK 07-13 [84] run by

For 2007-2013

Number of renewable energy projects Total value of RE projects (mln Polish zloties) EU funds for RE projects (mln Polish zloties) Types of projects by renewable energy sources Location of renewable energy investments Leading beneficiaries and partners the Ministry of Regional Development (name of the Ministry as of 31 January 2016, when the data was obtained), the data shows the state of arts as of 31 December 2015, according to the $\mathrm{n}+2 \mathrm{EU}$ regional policy rule [85], that allows the managing institutions in eligible member states to spend the EU funds allocations till the end of the second year after the year of receiving the funds, i.e., in case of 2007-2013 financial perspective till the end of 2015; from database containing 150,000 entries, we extracted entries describing all 264 investments in renewable energy, carried out by municipalities.

For 2014-2020:

Number of renewable energy projects

Total value of renewable energy projects ( $\mathrm{mln}$ Polish zloties)

EU funds for renewable energy projects (mln Polish zloties)

Types of projects by renewable energy sources

Location of renewable energy investments

Leading beneficiaries and partners

Qualitative and quantitative data on projects carried out in Poland under Operational Programmes 2014-2020, as of September 2020, obtained from the Central Teleinformation System SL 2014 run by the Ministry of Funds and Regional Policy, and retrieved on 1 December 2020 from [86], from the database containing 177,458 entries, we extracted 1161 entries describing 909 investments carried out by 638 municipalities, defined as leading beneficiaries.

The degree of urbanization (DEGURBA) classification categorizes municipalities into the three categories:

Types of municipalities by degree of urbanisation (DEGURBA) Code 1 - cities, or: densely populated areas

Code 2-towns and suburbs, or: intermediate density areas Code 3-rural areas, or: thinly populated areas retrieved on 30 June2020 from [87]

\begin{tabular}{ll}
\hline Tax ID of municipalities & National Court Register [88] accessed on 15 January 2021. \\
\hline TERYT codes, names and types of administrative units & $\begin{array}{l}\text { Database retrieved from the National Official Register of the } \\
\text { Territorial Division of the Country (TERYT), retrieved from [89]. }\end{array}$ \\
\hline addresses and codes of municipality offices & Data retrieved from the Public Information Bulletin [90]. \\
\hline
\end{tabular}

Table 2. Statistical methods and their application.

\begin{tabular}{ll}
\hline \multicolumn{1}{c}{ Method } & \multicolumn{1}{c}{ Applied to Test: } \\
\hline Kolmogorov-Smirnov test & $\begin{array}{l}\text { to what degree the distribution of the analyzed data categories was } \\
\text { skewed vs. normally distributed }\end{array}$ \\
\hline Kruskal-Wallis H test & $\begin{array}{l}\text { whether the total value of renewable energy projects and the share of EU } \\
\text { funds in the total value of renewable energy projects in 2007-2013 and } \\
2014-2020 \text { were significantly affected by the types of municipalities }\end{array}$ \\
\hline $\begin{array}{l}\text { Mann-Whitney U test } \\
\text { Wilcoxon rank-sum test }\end{array}$ & $\begin{array}{l}\text { whether there were significant differences in total value of renewable } \\
\text { energy projects, value of EU funds cofounding renewable energy projects } \\
\text { and the share of EU funds in total value of renewable energy projects } \\
\text { between different types of municipalities, i.e., those classified as cities, } \\
\text { towns and suburbs, and rural. }\end{array}$ \\
\hline Wilcoxon signed-rank test & $\begin{array}{l}\text { whether the total value of renewable energy projects and the value of EU } \\
\text { funds cofounding renewable energy projects differed between 2007-2013 } \\
\text { and 2014-2020 in case of the municipalities that carried out renewable } \\
\text { energy projects in both financial perspectives. }\end{array}$ \\
\hline
\end{tabular}

We looked into relations between various qualitative and quantitative features of objects assigned to one category (intra-case analysis) and attempted to define relations between different categories selected from the research sample (cross-case analysis) [91]. 


\section{Results}

\subsection{The Attitudes of Local Governments to Renewable Energy Investments}

The first part of the study on attitudes of local governments to renewable energy investments was based on the analysis of 292 local development strategies, retrieved from the websites of the municipalities in 2021. Therefore, the qualitative data set contains qualitative information on 93\% of all municipalities of Mazovian Voivodship.

The findings show that $85 \%$ of local governments declared the deployment of renewable energy. The types of renewable energy sources were indicated in $53.5 \%$ of the analyzed strategies. Other strategies contained only general information, emphasizing that renewable, also called alternative or ecological, energy sources should be deployed.

Among the 248 municipalities which accentuated the need to develop particular types of renewable energy, many referred to several different renewable energy sources at the same time. As many as $94.7 \%$ of them pointed out deployment of solar renewable energy, which is the most widespread renewable energy source in Poland, used for electricity production and heating purposes. Since solar energy is processed with the use of solar collectors and photovoltaic panels, $72.3 \%$ of the analysed strategies declared installation of solar collectors, and $22.3 \%$ photovoltaic panels.

Biomass and its particular types were indicated in $68.1 \%$ of strategies, which articulated the need to deploy renewable energy. Biomass consists of products, waste or residues from forest and agricultural production, which are biodegradable. It can also be biogas and some fractions of municipal and industrial waste. So, in 50\% of strategies local authorities stated that biomass is in general important as renewable energy sources, sometimes also biogas (6.4\%), energy plants (7.4\%) or a specific type of an energy plant, i.g. willow (4.3\%).

Referring to the source of renewable energy, $40.4 \%$ of analyzed strategies declared investments in wind energy, 20.2\% use of heat pumps, and 17\% geothermal energy. In addition, biofuels were mentioned in $16.0 \%$ of them. No strategy involved the analysis or description of conditions for renewable energy investments. No strategy defined what funds will be used to cover the costs of investments in renewable energy, although SWOT (strengths, weaknesses, opportunities, and threats) analyses of nearly all of them stated that the possibility of obtaining EU funding is a vital development opportunity.

In the next stage, the study on attitudes of local self-governments to renewable energy investments was based on qualitative datasets obtained from a survey of local governments carried out in 2017. The response rate at the level of 62\% provided answers of 195 local authorities. When asked about the most urgent investments in general, only $18 \%$ of respondents indicated renewable energy projects. However, they listed investments in renewable energy together with other urgent projects, such as construction or modernisation of roads, sewage systems, water system, support for home sewage system plants, and less of them together with water treatment plants and landfills. Other respondents ( $82 \%)$ listed only road, water supply and treatment, sewage and landfill investments as urgent.

Next, the respondents assessed the quality of the natural environment: $2 \%$ as very bad, $13 \%$ as bad, $56 \%$ as good and $29 \%$ as very good. Answering the question on investments necessary to improve the quality of natural environment in the municipality, $18 \%$ of respondents indicated renewable energy projects. However, most of them did not list the renewable energy projects as the most urgent for their municipality answering the earlier question. Cross-tabulation of so-far findings showed that all self-governments that listed investments in renewable energy as very urgent assessed the quality of natural environment in their municipalities either as good $(61 \%)$ or very good $(39 \%)$. Interestingly enough, none of those who listed investments in renewable energy as very urgent assessed the quality of natural environment as bad or very bad.

All respondents pointed at the lack of funding as the biggest obstacle in supporting the development of municipalities, both those who considered investments in renewable energy project as urgent, and those who did not. 
4.2. Local Governments' Renewable Energy Investments under Operational Programs 2007-2013 and 2014-2020

According to the assumptions of this study, the behaviour of local authorities was assessed based on their investments in renewable energy under operational programs 2007-2013 and 2014-2020, shown in SIMIK database for 2007-2013 (2015) financial perspective and in SL 2014 database for 2014-2020, as a still on-going financial perspective due to $n+2$ rule.

Over the analysed time local governments became more and more active in investing in renewable energy co-financed by the EU funds under operational programmes. In 2014-2020 compared to 2007-2013 there was a nearly threefold increase in the number of municipalities in Poland that carried out investments in renewable energy. In 2007-2013 it was $9.2 \%$ out of all 2479 municipalities in Poland, while in 2014-2020 it was 636 municipalities making $25.6 \%$ of all municipalities in the country (Table 3). Investigating rural-urban differences in the behaviour of local authorities we applied classification by the degree of urbanization (DEGURBA). The findings show that in 2007-2013 the shares of cities, towns and suburbs as well as rural municipalities, investing in renewable energy, were quite similar, respectively $11 \%, 10 \%$ and $9 \%$. In 2014-2020 these shares doubled for cities and towns and suburbs, as $20 \%$ of each of these groups invested in renewable energy. But rural municipalities became even more active. The share of rural municipalities who invested in renewable energy almost tripled in 2014-2020 compared to 2007-2013.

The increased activity of local governments in deploying renewable energy was also proved by the fact that more and more of them carried out more than only one project. Although in $2007-2013$ only $11 \%$ of municipalities carried out two projects and $1.7 \%$ municipalities three projects, in 2014-2020 the group of municipalities that carried out two and three projects increased significantly, up to $23.4 \%$ and $6.9 \%$ respectively. Moreover some of municipalities carried out four, six or even nine projects $(1.2 \% ; 0.2 \%$; $0.2 \%$, respectively). The increased activity of 111 local governments also shows in carrying out renewable energy investments co-financed by EU funds under operational programmes of both financial perspectives.

The increasing activity of local governments in deploying renewable energy was reflected in much higher mean total value of renewable energy projects carried out in 2014-2020 (Table 4), proving their bigger extent. This effect occurred most strongly in case of cities, which in 2014-2020 invested on average $10 \mathrm{mln}$ Polish zloties more in each renewable energy project than in 2007-2013. Rural municipalities invested on average $2.2 \mathrm{mln}$ more, which was the least increase, however they tripled the number of renewable energy projects as mentioned before.

The projects used mainly solar power and their share increased from $80 \%$ to $95 \%$. Other sources of renewable energy were less popular and their share even decreased: in case of projects using hydro-, geothermal and other renewable energy sources from $14 \%$ to $3 \%$ and in case of biomass from $5 \%$ to $1 \%$. Wind renewable energy projects made less than $1 \%$ of all renewable energy investments by municipalities. The investments resulted in modernization of heating systems for public buildings, installation of water heating systems for swimming pools, installation of economic lighting of municipal roads and squares, including hybrid lighting, biomass boiler networks together with the installation of solar collectors, installation of photovoltaics, Uniejów thermal baths.

The behavior of local authorities changed positively considering the collaboration in renewable energy projects. During the first financial perspective a prevailing majority of projects $(96 \%)$ was carried out by individual municipalities, only $4 \%$ of projects were carried out in collaboration at that time. This has changed during the on-going financial perspective as $28.7 \%$ of projects were carried out in collaboration between from two to 10 municipalities, and in one case even by 41 municipalities. Analysis of qualitative data shows that investing in renewable energy municipalities collaborated with other municipalities listed as partners, and with local residents mentioned in the descriptions of projects. 
Table 3. Number of municipalities-investors and renewable energy projects under operational programs of 2007-2013 and 2014-2020.

\begin{tabular}{|c|c|c|c|c|c|c|c|c|}
\hline \multirow{3}{*}{ Types of Municipalities } & \multicolumn{4}{|c|}{ Financial Perspective 2007-2013 } & \multicolumn{4}{|c|}{ Financial Perspective 2014-2020 } \\
\hline & \multicolumn{2}{|c|}{ Municipalities Investing in Renewable Energy } & \multicolumn{2}{|c|}{ Renewable Energy Projects } & \multicolumn{2}{|c|}{ Municipalities Investing in Renewable Energy } & \multicolumn{2}{|c|}{ Renewable Energy Projects } \\
\hline & No & $\%$ of All Municipalities of This Type & No & $\begin{array}{l}\text { \% of All Renewable Energy } \\
\text { Projects by Municipalities }\end{array}$ & No & $\%$ of All Municipalities of This Type & No & $\begin{array}{l}\text { \% of All Renewable Energy } \\
\text { Projects by Municipalities }\end{array}$ \\
\hline Towns and suburbs (2) & 54 & 10 & 61 & 23 & 103 & 20 & 165 & 18 \\
\hline Rural (3) & 167 & 9 & 188 & 72 & 513 & 27 & 695 & 77 \\
\hline All & 229 & 9.2 & 262 & 100 & 636 & 25.6 & 908 & 100 \\
\hline
\end{tabular}

Table 4. Descriptive statistics for RE investments carried out by municipalities in Poland in 2007-2013 and 2014-2020 EU financial perspectives, by types of municipalities.

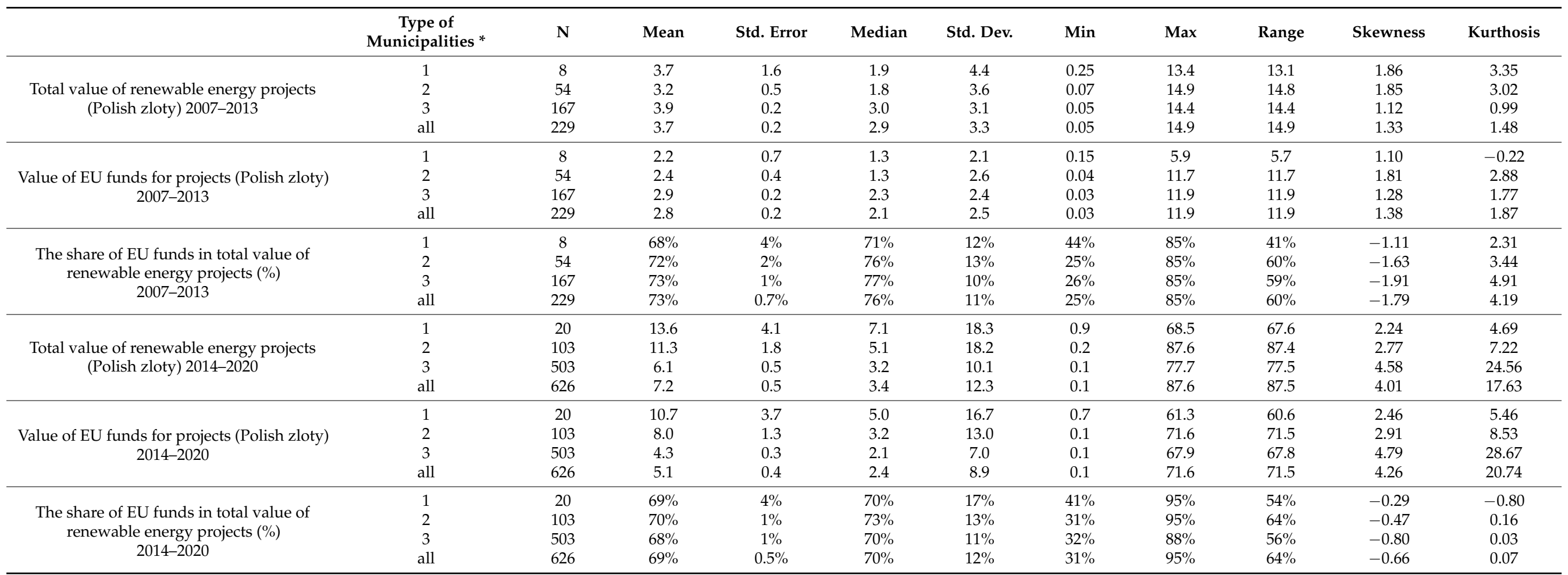

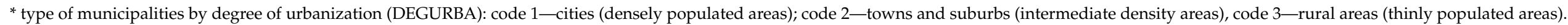


In case of projects carried out in collaboration, only one municipality was registered in adequate databases as the beneficiary, which significantly influences the interpretation of data on the number of beneficiaries and the number of renewable energy projects locations, shown in Figure 1 for the financial perspective 2007-2013 and in Figure 2 for 2014-2020.

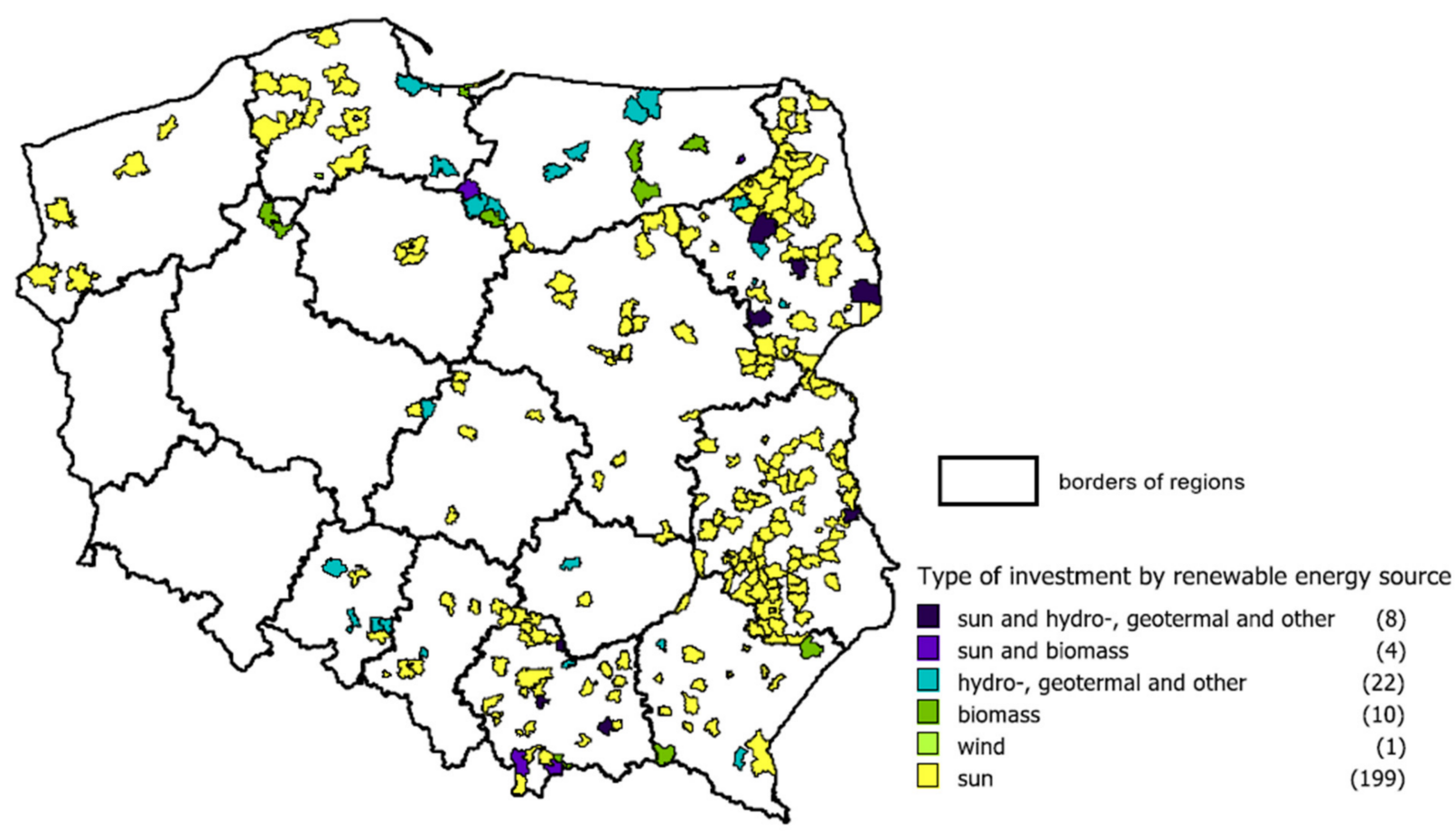

Figure 1. Location of renewable energy projects carried out by local authorities under operational programs 2007-2013, by the source of renewable energy.

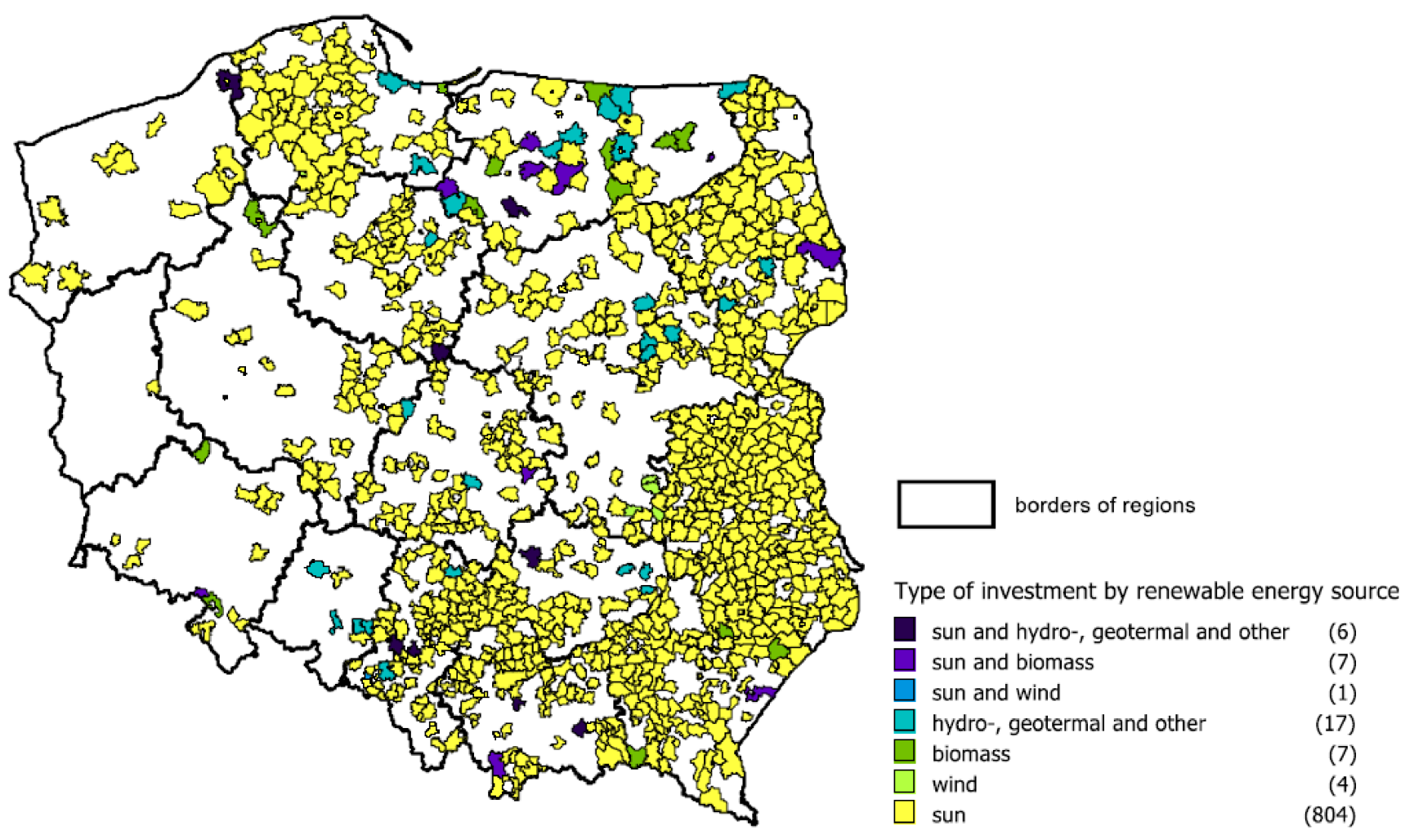

Figure 2. Location of renewable energy projects carried out by local authorities under operational programs 2014-2020 by the source of renewable energy. 
The increased collaboration means that there are more municipalities, actual beneficiaries of EU funding for renewable energy projects, than those shown in databases as 'leading beneficiaries'.

There are significant regional differences in the behavior of local authorities in the field of renewable energy investments under operational programs. More renewable energy projects were carried out in Podlaskie and Lubelskie Voivodships of Eastern Poland starting from 2007-2013, and the largest increase was also noted in those two regions. However, the number of renewable energy projects carried out by local governments also increased in regions of southern and northern parts of the country. Local governments of central regions were moderately active, and those in eastern Poland the least active in carrying out renewable energy projects co-financed by EU funds.

In both financial perspectives the renewable energy projects were co-financed by EU funds from the European Regional Development Fund. In 2007-2013 local authorities obtained these funds from the Operational Programme Infrastructure and Environment 2007-2013 (OPIE), which received the highest EU funding for any operational program in the history of EU regional and cohesion policy and from 16 regional operational programmes. In 2014-2020 the EU funds were obtained from 16 regional operational programmes. We tested whether the type of municipalities affected the total value of renewable energy projects and the share of EU funds in the total value of renewable energy projects using Kruskal-Wallis test (Table 5). The results show that the total value of renewable energy projects was not significantly affected by the types of municipalities in 2007-2013, but it was significantly affected in 2014-2020. The shares of EU funds in the total value of renewable energy projects were significantly affected by the types of municipalities neither in 2007-2013 nor in 2014-2020.

Table 5. Kruskal-Wallis tests for the type of municipalities vs. total value of renewable energy projects and the share of EU funds in the total value of renewable energy projects in 2007-2013 and 2014-2020.

\begin{tabular}{lcc}
\hline Kruskal-Wallis Tests Outcomes on & H(2) & $p$ \\
\hline $\begin{array}{l}\text { The types of municipalities affecting the total value of } \\
\text { renewable energy projects }\end{array}$ & \\
$\quad$ in 2007-2013 & 4.918 & $>0.86$ \\
in 2014-2020 & 12.629 & $>0.002$ \\
\hline $\begin{array}{l}\text { The types of municipalities affecting the share of EU funds } \\
\text { in the total value of renewable energy projects }\end{array}$ & \\
$\quad$ in 2007-2013 & 1.991 & $>0.37$ \\
in 2014-2020 & 2.157 & $>0.34$ \\
\hline
\end{tabular}

To investigate whether the total value, the value of European Union funds and their share in the total value of renewable energy projects differed significantly between cities, towns and suburbs, and rural municipalities in the consecutive financial perspectives, we ran Mann-Whitney tests, and Wilcoxon rank-sum test (Table 6), illustrated with descriptive statistics for these variables in (Tables 3 and 4 ).

Based on the results shown in Table 4 we conclude that these variables for cities (1) did not differ significantly from those for towns and suburbs (2), both in 2007-2013 and in 2014-2020. Most of the analyzed variables describing renewable energy projects by cities (1) did not differ significantly from those describing this kind of projects by rural municipalities (3). There are only two exceptions. The first is that the value of EU funds for the analyzed projects by cities was significantly different from that obtained for projects by rural municipalities in 2014-2020. The second is that the share of EU funds in the total value of renewable energy projects carried out by the cities was significantly different from the share of EU funds in the total value of renewable energy projects carried out by rural municipalities in 2007-2013. 
Table 6. Mann-Whitney U test for analyzed variables.

\begin{tabular}{|c|c|c|c|c|c|c|}
\hline \multirow{2}{*}{$\begin{array}{l}\text { Tests for Groups of } \\
\text { Municipalities }\end{array}$} & \multicolumn{2}{|c|}{$\begin{array}{l}\text { Total value of Renewable Energy } \\
\text { Projects in }\end{array}$} & \multicolumn{2}{|c|}{$\begin{array}{l}\text { European Union Funds Cofounding } \\
\text { Renewable Energy Projects in }\end{array}$} & \multicolumn{2}{|c|}{$\begin{array}{l}\% \text { of European Union Funds in Total Value } \\
\text { of Renewable Energy Projects in }\end{array}$} \\
\hline & $A^{*}$ & B ** & $A^{*}$ & B ** & $A^{*}$ & B ** \\
\hline \multicolumn{7}{|l|}{ (1) and (2) } \\
\hline Mann-Whitney $(U)$ & 203.000 & 890.000 & 204.000 & 925.000 & 175.000 & 970.500 \\
\hline Wilcoxon rank-sum $(W)$ & 1688.000 & 6246.000 & 1689.000 & 6281.000 & 211.000 & 6326.500 \\
\hline$Z$ & -0.273 & -0.960 & -0.252 & -0.720 & -0.861 & -0.408 \\
\hline Effect size $(r)$ & -0.020 & -0.071 & -0.019 & -0.053 & -0.063 & -0.030 \\
\hline Asympt. Sig. (2-tailed) & 0.785 & 0.337 & 0.801 & 0.472 & 0.389 & 0.683 \\
\hline Mt. Carlo Sig. (1-tailed $)^{\mathrm{b}}$ & 0.794 & 0.335 & 0.815 & 0.468 & 0.394 & 0.687 \\
\hline \multicolumn{7}{|l|}{ (1) and (3) } \\
\hline Mann-Whitney $(U)$ & 576.000 & 549.000 & 449.500 & 3426.500 & 3505.500 & 4882.000 \\
\hline Wilcoxon rank-sum $(W)$ & 612.000 & 585.000 & 485.500 & $130,182.500$ & $130,261.500$ & 5092.000 \\
\hline Z & -0.607 & -0.802 & -1.522 & -2.419 & -2.300 & -0.223 \\
\hline Effect size $(r)$ & -0.023 & -0.030 & -0.057 & -0.091 & -0.086 & -0.008 \\
\hline Asympt. Sig. (2-tailed) & 0.544 & 0.422 & 0.128 & 0.016 & 0.021 & 0.823 \\
\hline Mt. Carlo Sig. (1-tailed) ${ }^{\mathrm{b}}$ & 0.540 & 0.419 & 0.132 & 0.014 & 0.020 & 0.826 \\
\hline \multicolumn{7}{|l|}{ (2) and (3) } \\
\hline Mann-Whitney $(U)$ & 3571.000 & 3520.000 & 4350.000 & $21,382.000$ & $21,146.000$ & $23,530.000$ \\
\hline Wilcoxon rank-sum $(W)$ & 5056.000 & 5005.000 & 5835.000 & $148,138.000$ & $147,902.000$ & $28,886.000$ \\
\hline Z & -2.187 & -2.313 & -0.260 & -2.794 & -2.939 & -1.467 \\
\hline Effect size $(r)$ & -0.076 & -0.080 & -0.009 & -0.097 & -0.102 & -0.051 \\
\hline Asympt. Sig. (2-tailed) & 0.029 & 0.021 & 0.795 & 0.005 & 0.003 & 0.142 \\
\hline Mt. Carlo Sig. (1-tailed) ${ }^{\mathrm{b}}$ & 0.029 & 0.021 & 0.801 & 0.005 & 0.004 & 0.147 \\
\hline
\end{tabular}

A * -2007-2013 financial perspective; $B$ * -2014-2020 financial perspective; ${ }^{\mathrm{b}}$-based on a sample of 10,000 tables at the starting number $92,208,573$ of the generator of random numbers, ${ }^{* * *}$ types of municipalities coded as: (1) cities, (2) towns and suburbs and (3) rural municipalities. Grey cells show significant differences.

Some significant differences appeared between rural municipalities and those classified as towns and suburbs in the two financial perspectives. The total value of renewable energy projects carried by towns and suburbs was significantly different from that obtained by rural municipalities in 2007-2013 and similarly in 2014-2020. Alike in case of cities and rural municipalities, in 2014-2020 the value of EU funds for renewable energy projects by towns and suburbs was significantly different from that obtained by rural municipalities.

We tested whether the total value, the value of EU funding and the share of EU funding in the total value varied in the analyzed two financial perspectives using a Wilcoxon signedrank test (Table 7). Its results show, that both the total value of projects and the value of EU funds were higher in 2014-2020 than in 2007-2013, while the share of EU funds in the total value of renewable energy projects decreased in 2014-2020, which is explained by the fact that the increase in total value was higher than the increase in the value of EU funds.

Table 7. Wilcoxon signed-rank test for analyzed variables.

\begin{tabular}{|c|c|c|c|c|c|}
\hline & $\begin{array}{l}\text { Median 2007-2013 } \\
\text { (mln Polish Zloties) }\end{array}$ & $\begin{array}{l}\text { Median 2014-2020 } \\
\text { (mln Polish Zloties) }\end{array}$ & $\mathbf{T}$ & $p$-Value & Change $r$ \\
\hline $\begin{array}{l}\text { The total value of renewable } \\
\text { energy projects }\end{array}$ & 2.9 & 3.5 & 2021 & $<0.05$ & -0.29 \\
\hline European Union funds value & 2.1 & 2.4 & 2217 & $<0.05$ & -0.22 \\
\hline $\begin{array}{c}\text { The share of EU funds in the } \\
\text { total value of renewable } \\
\text { energy projects }\end{array}$ & $76 \%$ & $70 \%$ & 1632 & $<0.05$ & -0.49 \\
\hline
\end{tabular}

\section{Discussion}

Local authorities of $85 \%$ of the analyzed municipalities declared deployment of renewable energy in their municipalities as one of the aims of development strategies. However, the strategies themselves contained rather general information on the type of renewable energy that could be used. Additionally, none of the strategies involved analysis of the conditions for renewable energy development or the sources of funds for such investments. It shows that, although the strategies can be an important instrument of encouraging 
renewable energy development at the local and regional level in other countries [92-95], they are not used this way in Poland yet.

Although such a large share of local authorities declares deployment of renewable energy, many less of them find it the most urgent need. Knowing the local conditions and being obliged by the law to perform obligatory tasks, local authorities indicate construction or modernisation of roads, sewage systems, water system, support for home sewage system plants, and less of them together with water treatment plants and landfills as the most urgent. This hierarchy is also caused by local budgets constraints that do not allow local authorities to extend their investments beyond the obligatory tasks. These obstacles in developing renewable energy are also observed in other countries [96-98]. Referring to this problem, local authorities pointed at EU funds as a crucial factor moderating budget constraints. This is in line with many studies which prove that the success in introducing renewable energy largely depends on public aid [13].

Findings of our study prove that there is a substantial progress in the number and scope of investments in renewable energy carried out by local authorities in Poland under operational programmes 2007-2013 and 2014-2020. Taking into consideration rural-urban classification of municipalities, the cities, towns and suburbs doubled their renewable energy projects co-financed by the EU funds, while rural municipalities even tripled them. This is an important outcome as renewable energy is said to be an under-utilised resource both in urban and rural areas [99-101]. The increase in the intensity of renewable energy projects is reflected also by the fact that during 2014-2020 more communities carried out more than 1 renewable energy project.

In both analysed financial perspectives there were more renewable energy investments in the north and east of Poland. The numerous renewable energy projects in voivodships of Eastern Poland confirm that smaller and more remote communities may be more willing to deploy renewable energy [102], as regions of Eastern Poland are among the poorest in the EU.

During 2014-2020 there was a more widespread collaboration between local authorities and between local authorities and residents in carrying out renewable energy projects. The collaboration with the local population may increase their acceptance and support for developing renewable energy sources. Local acceptance is recognised as one of the main determinants of deploying renewable energy at the local level and transition towards decentralized energy systems and achieving regional energy self-sufficiency $[32,45,103,104]$. Mutual projects carried out by local authorities and municipality residents can have an added value. They may enable to 'experience benefits' and start a 'local participatory process' [105], by encouraging others to benefit from renewable energy and increase their support and commitment to renewable energy development. This is important as resistance or unwillingness of local population to new energy infrastructure may cause conflicts [106] and hinder achieving the EU goals [107]. None of the projects showed collaboration between local authorities and university, industry, or government, which could be favorable to increase renewable energy at local level [108].

Renewable energy projects carried out by communities used mainly sun renewable energy, which is the most easily accessible and relatively least controversial. The effects of projects improved energy efficiency of public buildings and public utilities, as well as family homes in case of projects carried out in collaboration with residents. Such effects are also observed in other countries [109]. The effects improved the quality of life which is are considered success factors in case of renewable energy projects carried out by local governments [104].

The use of EU funding (international aid) by local authorities proves that multilevel governance is effective and necessary to achieve the renewable energy and consequently sustainable development goals [110]. 


\section{Limitations}

As the study is based on a survey carried out in one of Polish regions and on the data for the EU supported projects, we think there may be two limitations to it. We sent the survey to all municipalities in Mazovian Voivodship and we achieved response rate of $62 \%$ for this largest region in Poland. However, local governments in other regions were not surveyed and their opinions may be different.

The other limitation may result from the fact that findings on the analysed effects of projects under operational programs tell an important, but possibly not the whole story on the behaviour of local governments towards renewable energy investments. Other sources of financing for such investments can be available to some local governments and used by them. Thus other studies should look into this matter.

\section{Conclusions}

According to the law, deployment of renewable energy is not an obligatory task for Polish local authorities. However, they are allowed to support its development. Based on the findings we claim that a majority of local authorities declare deployment of renewable energy as one of goals in the strategies of local development, but they do not perceive it the most urgent matter. In local governments' experience the catalogue of obligatory tasks together with budget constraints make renewable energy deployment less feasible and less urgent. Thus we conclude that the careful declarations on renewable energy deployment reflecting local authorities' attitudes are caused by the awareness of financial (dis)abilities of local budgets. However, possibilities of obtaining public aid, here EU funds, are a stimulus affecting local authorities' behaviour positively, resulting in the increasing number and scope of investments in renewable energy between consecutive financial perspectives.

There were significant differences in the number of local governments' renewable energy investments carried out in the regions of Western and Eastern Poland, but there were no regional differences in the sources-a prevailing majority of the analyzed projects used sun renewable energy. As many projects were carried out jointly by either different local governments or by local governments and residents, they improved energy efficiency of not only public buildings and public utilities, but also family homes. So it is recommended to promote such practices and achieved benefits of local collaboration to start or strengthen participatory processes in more local communities.

Drawing up on the findings and discussion, it is recommended that more public aid should be addressed to co-finance renewable energy projects carried out by local authorities. The principles of co-financing should be evidence-based and should promote practices that are best in a given social, economic and environmental context. Thus, further research into the attitudes and behaviour of local authorities and other actors should be carried out to provide a basis for multilevel decisions on the deployment of renewable energy.

Author Contributions: Conceptualization, J.R.; methodology, J.R. and I.O.; validation, J.R.; formal analysis, J.R. and I.O.; investigation, J.R. and I.O.; data curation, J.R.; writing-original draft preparation, J.R. and I.O.; writing-review and editing J.R.; visualization, J.R.; supervision, J.R. and I.O.; project administration, J.R.; funding acquisition, J.R. and I.O. Both authors have read and agreed to the published version of the manuscript.

Funding: This research received no external funding.

Institutional Review Board Statement: Not applicable.

Informed Consent Statement: Not applicable.

Data Availability Statement: Not applicable.

Conflicts of Interest: The authors declare no conflict of interest. 


\section{References}

1. UNFCCC. United Nations Framework Convention on Climate Change. 1994. Available online: https://unfccc.int/process-andmeetings/the-convention/what-is-the-united-nations-framework-convention-on-climate-change (accessed on 15 February 2021).

2. Kyoto Protocol. Reference Manual on Accounting of Emissions and Assigned Amount, UNFCCC. 1997. Available online: https://unfccc.int/sites/default/files/08_unfccc_kp_ref_manual.pdf (accessed on 15 December 2020).

3. Paris Agreement. United Nations 2015. Available online: https://unfccc.int/sites/default/files/english_paris_agreement.pdf (accessed on 30 September 2020).

4. European Council. 2030 Climate and Energy Policy Framework; European Council: Brussels, Belgium, 2014.

5. Lucas, J.N.V.; Francés, G.E.; González, E.S.M. Energy security and renewable energy deployment in the EU: Liaisons Dangereuses or Virtuous Circle? Renew. Sustain. Energy Rev. 2016, 62, 1032-1046. [CrossRef]

6. Benedek, J.; Tihamér-Tibor, S.; Bartók, B. Evaluation of renewable energy sources in peripheral areas and renewable energy-based rural development. Renew. Sustain. Energy Rev. 2018, 90, 516-535. [CrossRef]

7. $\operatorname{COM(2010)639~Final,~COM(2010)~} 639$ Final of 10 November 2010 'Energy 2020: A Strategy for Competitive, Sustainable and Secure Energy'; SEC(2010) 1346; European Commission: Brussels, Belgium, 10 November 2010.

8. Negro, S.O.; Alkemade, F.; Hekkert, M.P. Why does renewable energy diffuse so slowly? A review of innovation system problems. Renew. Sustain. Energy Rev. 2012, 16, 3836-3846. [CrossRef]

9. Alonso, P.M.; Hewitt, R.; Díaz-Pacheco, J.; Bermejo, L.R.; Hernández-Jiménez, V.; Guillén, J.V.; Bressers, H.; de Boer, C. Losing the roadmap: Renewable energy paralysis in Spain and its implications for the EU low carbon economy. Renew. Energy 2016, 89, 680-694. [CrossRef]

10. OECD. Linking Renewable Energy to Rural Development, OECD Green Growth Studies; OECD Publishing: Paris, France, 2016. [CrossRef]

11. Leikučs, J.; Strīkis, V. An overview of legislative and institutional barriers of Latvia's renewable energy production. Manag. Theory Stud. Rural Bus. Infrastruct. Dev. 2011, 2, 146-155.

12. Rennkamp, B.; Haunss, S.; Wongsa, K.; Ortega, A.; Casamadrid, E. Competing coalitions: The politics of renewable energy and fossil fuels in Mexico, South Africa and Thailand. Energy Res. Soc. Sci. 2017, 34, 214-223. [CrossRef]

13. Stokes, L.C.; Breetz, H.L. Politics in the U.S. energy transition: Case studies of solar, wind, biofuels and electric vehicles policy. Energy Policy 2018, 113, 76-86. [CrossRef]

14. Stokes, L.C. The politics of renewable energy policies: The case of feed-in-tariffs in Ontario, Canada. Energy Policy 2013, 56, 490-500. [CrossRef]

15. Prados, M.-J. Renewable energy policy and landscape management in Andalusia, Spain: The facts. Energy Policy 2010, 38, 6900-6909. [CrossRef]

16. Cansino, J.M.; Pablo-Romero, M.P.; Román, R.; Yñiguez, R. Promoting renewable energy sources for heating and cooling in EU-27 countries. Energy Policy 2011, 39, 3803-3812. [CrossRef]

17. Peidong, Z.; Yanli, Y.; Jin, S.; Yonghong, Z.; Lisheng, W.; Xinrong, L. Opportunities and challenges for renewable energy policy in China. Renew. Sustain. Energy Rev. 2009, 13, 439-449. [CrossRef]

18. Boon, F.P.; Dieperink, C. Local civil society based renewable energy organisations in the Netherlands: Exploring the factors that stimulate their emergence and development. Energy Policy 2014, 69, 297-307. [CrossRef]

19. White, W.; Lunnan, A.; Nybakk, E.; Kulisic, B. The role of governments in renewable energy: The importance of policy consistency. Biomass Bioenergy 2013, 57, 97-105. [CrossRef]

20. EC. Energy for the Future: Renewable Sources of Energy; White Paper for a Community Strategy and Action Plan, COM(97) 599 Final; EC: Brussels, Belgium, 1997.

21. Blok, K. Renewable energy policies in the European Union. Energy Policy 2006, 34, 251-255. [CrossRef]

22. Klessmann, C.; Held, A.; Rathmann, M.; Ragwitz, M. Status and perspectives of renewable energy policy and deployment in the European Union-What is needed to reach the 2020 targets? Energy Policy 2011, 39, 7637-7657. [CrossRef]

23. Helm, D. The European framework for energy and climate policies. Energy Policy 2014, 64, 29-35. [CrossRef]

24. D'Adamo, R.P. Current state of renewable energies performances in the European Union: A new reference framework. Energy Convers. Manag. 2016, 121, 84-92. [CrossRef]

25. Veum, K.; Bauknecht, D. How to reach the EU renewables target by 2030? An analysis of the governance framework. Energy Policy 2019, 127, 299-307. [CrossRef]

26. Tagliapietra, S.; Zachmann, G.; Edenhofer, O.; Glachant, J.-M.; Linares, P.; Loeschel, A. The European Union energy transition: Key priorities for the next five years. Energy Policy 2019, 132, 950-954. [CrossRef]

27. Directive 2009/28/EC of the European Parliament and of the Council of 23 April 2009 on the Promotion of the Use of Energy from Renewable Sources and Amending and Subsequently Repealing Directives 2001/77/EC and 2003/30/EC ('RES Directive') (OJ L 140, 5.6.2009). Available online: https:/ / eur-lex.europa.eu/legal-content/EN/ALL/?uri=celex\%3A32009L0028 (accessed on 30 September 2020). 
28. Regulation (EU) 2018/1999 of the European Parliament and of the Council of 11 December 2018 on the Governance of the Energy Union and Climate Action, amending Regulations (EC) No 663/2009 and (EC) No 715/2009 of the European Parliament and of the Council, Directives 94/22/EC, 98/70/EC, 2009/31/EC, 2009/73/EC, 2010/31/EU, 2012/27/EU and 2013/30/EU of the European Parliament and of the Council, Council Directives 2009/119/EC and (EU) 2015/652 and repealing Regulation (EU) No 525/2013 of the European Parliament and of the Council. Available online: https:/ / eur-lex.europa.eu/legal-content/EN/TXT/ ?uri=uriserv\%3AOJ.L_.2018.328.01.0001.01.ENG (accessed on 30 September 2020).

29. European Commission 2014. A Policy Framework for Climate and Energy in the Period from 2020 to 2030; COM(2014) 15 Final; European Commission: Brussels, Belgium, 2014; Available online: https://eur-lex.europa.eu/legal-content/EN/ALL/?uri= celex\%3A52014DC0015 (accessed on 30 September 2020).

30. European Court of Auditors. Cohesion Policy Funds Support to Renewable Energy Generation-Has It Achieved Good Results? Publications Office of the European Union, European Union: Luxembourg, 2014. [CrossRef]

31. IRENA. Global Energy Transformation: A Roadmap to 2050; International Renewable Energy Agency: Abu Dhabi, United Arab Emirates, 2019.

32. IEA-International Energy Agency: Cities, Towns \& Renewable Energy; Yes in My Front Yard; IEA: Paris, France, 2009.

33. Bulkeley, H.; Kern, K. Local Government and the Governing of Climate Change in Germany and the UK. Urban Stud. 2006, 43, 2237-2259. [CrossRef]

34. Müller, M.O.; Stämpfli, A.; Dold, U.; Hammer, T. Energy autarky: A conceptual framework for sustainable regional development. Energy Policy 2011, 39, 5800-5810. [CrossRef]

35. Burgess, P.J.; Rivas Casado, M.; Gavu, J.; Mead, A.; Cockerill, T.; Lord, R.; van der Horst, D.; Howard, D.C. A framework for reviewing the trade-offs between, renewable energy, food, feed and wood production at a local level. Renew Sustain. Energy Rev. 2012, 16, 129-142. [CrossRef]

36. Emelianoff, C. Local Energy Transition and Multilevel Climate Governance: The Contrasted Experiences of Two Pioneer Cities (Hannover, Germany, and Växjö, Sweden). Urban Stud. 2014, 51, 1378-1393. [CrossRef]

37. Schnidt, B.; Meister, T.; Klagge, B.; Seidl, I. Energy Cooperatives and Municipalities in Local Energy Governance Arrangements in Switzerland and Germany. J. Environ. Dev. 2020, 29, 123-146.

38. Río, P.; Burguillo, M. An empirical analysis of the impact of renewable energy employment on local sustainability. Renew. Sustain. Energy Rev. 2009, 13, 1314-1325.

39. Poggi, F.; Firmino, A.; Amado, M. Planning renewable energy in rural areas: Impacts on occupation and land use. Energy 2018, 155, 630-640. [CrossRef]

40. Dvořák, P.; Martinát, S.; Van der Horst, D.; Frantál, B.; Turečková, K. Renewable energy investment and job creation; a crosssectoral assessment for the Czech Republic with reference to EU benchmarks. Renew. Sustain. Energy Rev. 2017, 69, 360-368. [CrossRef]

41. Shirley, R.; Kammen, D. Renewable energy sector development in the Caribbean: Current trends and lessons from history. Energy Policy 2013, 57, 244-252. [CrossRef]

42. Schneider, D.R.; Duić, N.; Bogdan, Ž. Mapping the potential for decentralized energy generation based on renewable energy sources in the Republic of Croatia. Energy 2007, 32, 1731-1744. [CrossRef]

43. Nepal, R. Roles and potentials of renewable energy in less-developed economies: The case of Nepal. Renew. Sustain. Energy Rev. 2012, 16, 2200-2206. [CrossRef]

44. Gonda, G. Utilization of renewable energies and changing energy structure at local government, as drivers of economic recovery: Hungarian case study. Int. J. Soc. Sci. Humanit. Stud. 2011, 3, 267-276.

45. Karanasios, K.; Parker, P. Explaining the Diffusion of Renewable Electricity Technologies in Canadian Remote Indigenous Communities through the Technological Innovation System Approach. Sustainability 2018, 10, 3871. [CrossRef]

46. Creutzig, F.; Goldschmidt, J.C.; Lehmann, P.; Schmid, E.; von Blücher, F.; Breyer, C.; Fernandez, B.; Jakob, M.; Knopf, B.; Lohrey, S.; et al. Catching two European birds with one renewable stone: Mitigating climate change and Eurozone crisis by an energy transition. Renew. Sustain. Energy Rev. 2014, 38, 1015-1028. [CrossRef]

47. García-Gusano, D.; Iribarren, D.; Dufour, J. Towards Energy Self-sufficiency in Large Metropolitan Areas: Business Opportunities on Renewable Electricity in Madrid. In Renewable Energies; García Márquez, F., Karyotakis, A., Papaelias, M., Eds.; Springer International Publishing: Cham, Switzerland, 2018. [CrossRef]

48. Li, L.W.; Birmelea, J.; Schaicha, H.; Werner, K. Transitioning to community-owned renewable energy: Lessons from Germany. Procedia Environ. Sci. 2013, 17, 719-728. [CrossRef]

49. Lowitzsch, J.; Hoicka, C.E.; van Tulder, F.J. Renewable energy communities under the 2019 European Clean Energy PackageGovernance model for the energy clusters of the future? Renew. Sustain. Energy Rev. 2020, 122. [CrossRef]

50. Lilliestam, J.; Hanger, S. Shades of green: Centralisation, decentralisation and controversy among European renewable electricity visions. Energy Res. Soc. Sci. 2016, 17, 20-29. [CrossRef]

51. McKenna, R.; Bertsch, V.; Mainzer, K.; Fichtner, W. Combining local preferences with multi-criteria decision analysis and linear optimization to develop feasible energy concepts in small communities. Eur. J. Oper. Res. 2018, 268, 1092-1110. [CrossRef]

52. Tröndle, T.; Pfenninger, S.; Lilliestam, J. Home-made or imported: On the possibility for renewable electricity autarky on all scales in Europe. Energy Strategy Rev. 2019, 26, 100388. [CrossRef] 
53. Kostevsek, A.; Cizelj, L.; Petek, J.; Cucek, L.; Varbanov, P.S.; Klemes, J.J.; Pivec, A. Use of renewables in rural municipalities' integrated energy systems. Chem. Eng. Trans. 2013, 35, 895-900.

54. Petersen, J.P. Energy concepts for self-supplying communities based on local and renewable energy sources: A case study from northern Germany. Sustain. Cities Soc. 2016, 26, 1-8. [CrossRef]

55. Engelken, M.; Römer, B.; Drescher, M.; Welpe, I. Transforming the energy system: Why municipalities strive for energy selfsufficiency. Energy Policy 2016, 98, 365-377. [CrossRef]

56. Mathiesen, B.V.; Lund, H.; Karlsson, K. 100\% Renewable energy systems, climate mitigation and economic growth. Appl. Energy 2011, 88, 488-501. [CrossRef]

57. Fraser, T. Does social capital boost or block renewable energy sitting? South African solar politics in comparison. Energy Res. Soc. Sci. 2021, 71, 101845. [CrossRef]

58. Comodi, G.; Cioccolanti, L.; Polonara, F.; Brandoni, C. Local authorities in the context of energy and climate policy. Energy Policy 2012, 51, 737-748. [CrossRef]

59. Cheung, G.; Davies, P.J.; Trück, S. Transforming urban energy systems: The role of local governments' regional energy master plan. J. Clean. Prod. 2019, 220, 655-667. [CrossRef]

60. Fouché, E.; Brent, A. Journey towards Renewable Energy for Sustainable Development at the Local Government Level: The Case of Hessequa Municipality in South Africa. Sustainability 2019, 11, 755. [CrossRef]

61. Mey, F.; Diesendorf, M.; MacGill, I. Can local government play a greater role for community renewable energy? A case study from Australia. Energy Res. Soc. Sci. 2016, 21, 33-43. [CrossRef]

62. United Nations Sustainable Development Goals Report 2016; U.N. Publications: New York, NY, USA, 2016.

63. Sperling, K.; Hvelplund, F.; Mathiesen, B.V. Centralisation and decentralisation in strategic municipal energy planning in Denmark. Energy Policy 2011, 39, 1338-1351. [CrossRef]

64. Gronkowska, J. Model energy cluster-Special energy zone delivering integrated territorial energy. Geomat. Landmanag. Landsc. 2017, 3, 47-57. [CrossRef]

65. Węglarz, A.; Winkowska, E.; Wójcik, W. Gospodarka Niskoemisyjna Zaczyna się w Gminie. Podręcznik dla Polskich Samorządów; Adelphi: Berlin, Germany, 2015.

66. Kosiński, E.; Trupkiewicz, M. Gmina jako podmiot systemu wspierania wytwarzania energii elektrycznej z odnawialnych źródeł energii (A municipality as a part of the suport system for generetion of electricity from renewable energy sources). Ruch Praw. Ekon. Socjol. 2016, 78, 93-107.

67. Kompendium Wiedzy o Unii Europejskiej; Małuszyńska, E.; Gruchman, B. (Eds.) Wyd. Naukowe PWN: Warsaw, Poland, 2005.

68. European Charter of Local Self-Government. 1985. Available online: https://www.coe.int/en/web/conventions/full-list/-/ conventions/rms/090000168007a088 (accessed on 30 September 2019).

69. The Act of 10 April 1997, Energy Law, Ustawa z dnia 10 kwietnia 1997 r. Prawo energetyczne. Tekst jedn.: DzU z 2020 r. poz. 833 z późn. zm. Available online: http:/ /isap.sejm.gov.pl/isap.nsf/DocDetails.xsp?id=wdu19970540348 (accessed on 30 September 2020).

70. The Act of 20 February 2015 on Renewable Energy Sources, Ustawa z dnia 20 lutego 2015 r. o odnawialnych źródłach energii. Tekst jedn.: DzU z 2020 r. poz. 261 z późn. zm. Available online: http:/ / isap.sejm.gov.pl/isap.nsf/DocDetails.xsp?id=wdu20150000478 (accessed on 30 September 2019).

71. The Act of May 20, 2016 on Investments in Wind Farms. Ustawa z dnia 20 maja 2016 r. o inwestycjach w zakresie elektrowni wiatrowych. Tekst jedn.: DzU z 2020 r. poz. 981 z późn. zm. Available online: https://isap.sejm.gov.pl/isap.nsf/DocDetails.xsp? id=WDU20160000961 (accessed on 30 September 2019).

72. Rakowska, J. Fundusze unijne jako czynnik rozwoju obszarów wiejskich w Polsce w świetle teorii rozwoju lokalnego; Wydawnictwo SGGW: Warsaw, Poland, 2019.

73. The Act of March 8, 1990 on the Municipality Self-Government, JoL of 2020, Item 713. Available online: https:/ /isap.sejm.gov.pl/ isap.nsf/DocDetails.xsp?id=WDU19900160095 (accessed on 30 September 2019).

74. Local Administrative Units (LAU). Available online: https://ec.europa.eu/eurostat/web/nuts/local-administrative-units (accessed on 30 September 2020).

75. Szyrski, M. Rola samorzadu terytorialnego w rozwoju odnawialnych źródeł energii (OZE). Analiza administracyjnoprawna; Wolters Kluwer: Warsaw, Poland, 2017.

76. Swora, M. Organy właściwe w sprawach energetyki (charakter, zadania i kompetencje). In System Prawa Administracyjnego, t. 8B, Publiczne prawo gospodarcze; Hauser, H., Niewiadomski, Z., Wróbel, A., Eds.; C.H. Beck: Warsaw, Poland, 2013.

77. Szyrski, M. Ocena realizacji konstytucyjnej zasady pomocniczości w prawie odnawialnych źródeł energii. Samorząd Terytorialny 2018, 5, 21-31.

78. Directive (EU) 2018/2001 of the European Parliament and of the Council of 11 December 2018 on the Promotion of the Use of Energy from Renewable Sources (Text with EEA Relevance) OJ L 328; European Commission: Brussels, Belgium, 21 December 2018 ; pp. 82-209.

79. Rakowska, J. European Union Regional Policy Support for Investments in Renewable Energy in Rural Areas of the Mazovian Voivodship. Roczniki Naukowe Stowarzyszenia Ekonomistów Rolnictwa i Agrobiznesu 2020, 22, 279-288. [CrossRef]

80. NUTS 1 Classification. Available online: https:/ / ec.europa.eu/eurostat/documents/345175/7451602/NUTS1-changes-2016-to2021.pdf (accessed on 30 September 2020).

81. Silverman, D. Doing Qualitative Research, 2nd ed.; Sage Publications: London, UK, 2005.

82. Charmaz, K. Teoria Ugruntowana. Praktyczny Przewodnik po Analizie Jakościowej; Wydawnictwo PWN: Warsaw, Poland, 2009. 
83. Glaser, B.G.; Strauss, A.L. Odkrywanie Teorii Ugruntowanej. Strategie Badania Jakościowego; Nomos: Cracov, Poland, 2009.

84. National Information System SIMIK. Available online: https://archiwum.miir.gov.pl/strony/zadania/fundusze-europejskie/ wykorzystanie-projekty-i-efekty-funduszy-europejskich/fundusze-europejskie-na-lata-2007-2013/projekty-zrealizowane-zfunduszy / (accessed on 15 January 2016).

85. The $\mathrm{n}+2$ Explanation. Available online: https://ec.europa.eu/regional_policy/en/policy/what/glossary/n/nplus2 (accessed on 21 January 2021).

86. Database of Implemented EU Projects; Ministry of Development Funds and Regional Policy: Warsaw, Poland. Available online: https:/ / www.funduszeeuropejskie.gov.pl/strony/o-funduszach/projekty/lista-projektow /lista-projektow-realizowanychzfunduszy-europejskich-w-polsce-w-latach-2014-2020/ (accessed on 22 September 2020).

87. DEGURBA Classification. Available online: https://ec.europa.eu/eurostat/ramon/miscellaneous/index.cfm?TargetUrl=DSP_ DEGURBA (accessed on 21 January 2021).

88. National Court Register. Available online: https://www.gov.pl/web/sprawiedliwosc/krajowy-rejestr-sadowy (accessed on 21 January 2021).

89. National Official Register of the Territorial Division of the Country (TERYT). Available online: https://eteryt.stat.gov.pl/eTeryt/ rejestr_teryt/udostepnianie_danych/baza_teryt/uzytkownicy_indywidualni/wyszukiwanie/wyszukiwanie.aspx?contrast= default (accessed on 10 January 2021).

90. Biuletyn Informacji Publicznej (BIP). Available online: https:/ / www.bip.gov.pl (accessed on 21 January 2021).

91. Berkowitz, S. Using Qualitative and Mixed Method Approaches. In Needs Assessment: A Creative and Practical Guide for Social Scientists; Reviere, R., Berkowitz, S., Carter, C.C., Graves-Ferguson, C., Eds.; Taylor \& Francis Publishing House: Washington, DC, USA, 1996.

92. Jones, E.; Leach, M. Devolving Residential Energy Efficiency Responsibility to Local Government: The case of HECA. Local Environ. 2000, 5, 69-81. [CrossRef]

93. Terrados, J.; Almonacid, G.; Hontoria, L. Regional energy planning through SWOT analysis and strategic planning tools: Impact on renewables development. Renew. Sustain. Energy Rev. 2007, 11, 1275-1287. [CrossRef]

94. Petersen, J.P. The application of municipal renewable energy policies at community level in Denmark: A taxonomy of implementation challenges. Sustain. Cities Soc. 2018, 38, 205-218. [CrossRef]

95. Thellufsen, J.K.; Lund, H. Roles of local and national energy systems in the integration of renewable energy. Appl. Energy 2016, 183, 419-429. [CrossRef]

96. Collier, U. Local authorities and climate protection in the European Union: Putting subsidiarity into practice? Local Environ. 1997, 2, 39-57. [CrossRef]

97. Morell, I.A. Can Renewable Energy Contributo to Poverty Reduction? A Case Study on Romafa, a Hungarian LEADER. In Evaluating the European Approach to Rural Development: Grass-Roots Experiences of the LEADER Programme; Granberg, L., Adersson, K., Kovách, I., Eds.; Routledge Taylor \& Francis Group: London, UK; New York, NY, USA, 2015.

98. Busch, H.; McCormick, K. Local power: Exploring the motivations of mayors and key success factors for local municipalities to go 100\% renewable energy. Energy Sustain. Soc. 2014, 4, 1-15. [CrossRef]

99. Villamor, E.; Akizu-Gardoki, O.; Azurza, O.; Urkidi, L.; Campos-Celador, A.; Basurko, I.; Barcena Hinojal, I. European Cities in the Energy Transition: A Preliminary Analysis of 27 Cities. Energies 2020, 13, 1315. [CrossRef]

100. Hoesen, V.J.; Letendre, S. Evaluating potential renewable energy resources in Poultney, Vermont: A GIS-based approach to supporting rural community energy planning. Renew. Energy 2010, 35, 2114-2122. [CrossRef]

101. Sait, M.A.; Chigbu, U.E.; Hamiduddin, I.; De Vries, W.T. Renewable Energy as an Underutilised Resource in Cities: Germany's 'Energiewende' and Lessons for Post-Brexit Cities in the United Kingdom. Resources 2019, 8, 7. [CrossRef]

102. St. Denis, G.; Parker, P. Community energy planning in Canada: The role of renewable energy. Renew. Sustain. Energy Rev. 2009, 13, 2088-2095. [CrossRef]

103. Michalena, E.; Angeon, V. Local challenges in the promotion of renewable energy sources: The case of Crete. Energy Policy 2009, 37, 2018-2026. [CrossRef]

104. Allman, L.; Fleming, P.; Wallace, A. The progress of English and Welsh local authorities in addressing climate change. Local Environ. 2004, 9, 271-283. [CrossRef]

105. Süsser, D.; Kannen, A. 'Renewables? Yes, please!': Perceptions and assessment of community transition induced by renewableenergy projects in North Frisia. Sustain. Sci. 2017, 12, 563-578. [CrossRef]

106. Walker, G. Renewable energy and the public. Land Use Policy 1995, 12, 49-59. [CrossRef]

107. Azarova, V.; Jed, C.; Friedl, C.; Reichl, J. Designing local renewable energy communities to increase social acceptance: Evidence from a choice experiment in Austria, Germany, Italy, and Switzerland. Energy Policy 2019, 132, 1176-1183. [CrossRef]

108. Lerman, L.V.; Gerstlberger, W.; Ferreira Lima, M.; Frank, A.G. How governments, universities, and companies contribute to renewable energy development? A municipal innovation policy perspective of the triple helix. Energy Res. Soc. Sci. 2021, 71, 101854. [CrossRef]

109. Fiaschi, D.; Bandinelli, R.; Conti, S. A case study for energy issues of public buildings and utilities in a small municipality: Investigation of possible improvements and integration with renewables. Appl. Energy 2012, 97, 101-114. [CrossRef]

110. Bulkeley, H.; Betsil, M.E. Rethinking Sustainable Cities: Multilevel Governance and the 'Urban' Politics of Climate Change. Environ. Politics 2005, 14, 42-63. [CrossRef] 